\title{
Auxin (IAA) and soluble carbohydrate seasonal dynamics monitored during xylogenesis and phloemogenesis in Scots pine
}

\author{
Marek Fajstavr ${ }^{(1-2)}$, \\ Zuzana Paschová (1), \\ Kyriaki Giagli ${ }^{(1)}$, \\ Hanuš Vavrčík ${ }^{(1)}$, \\ Vladimír Gryc ${ }^{(1)}$, \\ Josef Urban ${ }^{(3-4)}$
}

\begin{abstract}
The metabolic activity of phytohormones and the accumulation of carbohydrates affect the reactivation of the cambial zone and the radial increment of woody plants. We aimed to monitor the dynamics of indole-3-acetic acid (IAA) concentration and amounts of soluble carbohydrates during xylem and phloem formation of one growing season (2015). Six sample trees of Scots pine (Pinus sylvestris L.), aged 80 years on average, growing in the Sobešice research site (404 m a.s.l.) in the Czech Republic were selected. We obtained microcore samples at weekly intervals by the Trephor tool method for cell formation analysis and spectrophotometric determination of IAA and soluble carbohydrate contents. We found that time of the highest concentration of IAA (last week of April) coincided with time of the maximum number of cells in the cambial zone and highest expansion of the cell enlargement stage. When the IAA concentration was too low to be measured, latewood tracheids started to form, and late phloem sieve cell formation ceased. The highest concentration of soluble carbohydrates was $200.40 \pm 21.6 \mu \mathrm{g} \mathrm{GLU}$ per sample (May 14). This coincided with the fastest weekly xylem cell increment. This research shows that IAA and soluble carbohydrate dynamics directly affects xylem and phloem formation.
\end{abstract}

Keywords: Pinus sylvestris L., Indole-3-Acetic Acid, Xylem, Phloem, Tracheids, Earlywood, Latewood

\section{Introduction}

One of the most important processes for formation of xylem and phloem is the be ginning of cambial activity. In addition to air temperature and soil moisture content (Oribe et al. 2001, Deslauriers et al. 2008, Lupi et al. 2010), the reactivation of the cambial zone and the beginning of new cell formation substantially depend on the metabolic activities of plant hormones (phytohormones). Phytohormones are nat ural secondary metabolites of plants, and their concentrations affect cambial activity and, subsequently, differentiation of form ing tissues; thus they act as growth regula tors. Namely, they participate in cell divi-

sion, enlargement and differentiation, as they have a key role in organ development and senescence. Auxin, ethylene, abscisic acid, gibberellins, cytokinins, jasmonates, brassinosteroids and salicylates are currently recognized as phytohormones (Teale et al. 2006, Fu et al. 2011). The role of phytohormone transport is not elucidated. The extent and significance of auxin concentration, though, is considered particularly important (Teale et al. 2006). Unlike other phytohormones, auxin concentration is not controlled only by homeostatic mechanisms (biosynthesis, conjugation and catabolism) of the plant. The direction of auxin flux also involves active transport of

(1) Department of Wood Science, Faculty of Forestry and Wood Technology, Mendel University in Brno, Zemědělská 3, 61300 Brno (Czech Republic); (2) The Czech Academy of Sciences, CzechGlobe - Global Change Research Institute, Institute of Plant Water Balance and Biomass Production, Belidla 4a, 60300 Brno (Czech Republic); (3) Department of Forest Botany, Dendrology and Geobiocenology, Faculty of Forestry and Wood Technology, Mendel University in Brno, Zemědělská 3, 61300 Brno (Czech Republic); (4) Siberian Federal University, Svobodnyj Prospect 79, Krasnoyarsk, 660041 Krasnoyarsk (Russia)

@ Marek Fajstavr (fajstavr.maara@gmail.com)

Received: Jan 19, 2018 - Accepted: Jun 26, 2018

Citation: Fajstavr M, Paschová Z, Giagli K, Vavrčík H, Gryc V, Urban J (2018). Auxin (IAA) and soluble carbohydrate seasonal dynamics monitored during xylogenesis and phloemogenesis in Scots pine. iForest 11: 553-562. - doi: 10.3832/ifor2734-011 [online 2018-09-01]

the hormone in a polar way (Vanneste \& Friml 2009). The main pathway for polar auxin transport in the stem is the cambial zone area (Sundberg et al. 2000). This is considered to be unique from a biochemical perspective in regard to wood formation because wood cells generally demonstrate a notably low capacity for performing homeostatic mechanisms (Schrader et al. 2003).

Many vital phytohormones, essential for plant growth and development, are grouped under the auxin category, but indole-3-acetic acid (IAA) is considered to be the predominant and the most abundant auxin in plants (Nakurte et al. 2012). IAA is a major regulator of plant growth and development (Perrot-Rechenmann 2010), mainly controlling meristematic function, cell enlargement, and overall cell expansion (Carlsbecker \& Helariutta 2005, Sieburth \& Deyholos 2006). Nevertheless, only a small percentage of IAA resides in a free form in plants, while most of it is conjugated to amino acids and sugars (Nakurte et al. 2012). IAA is distributed from plant assimilation organ chloroplasts through their entire vascular system down to the root apex, and IAA is also a part of assimilate flow through phloem sieve cells to heterotrophic parts of woody plants (Aloni 1995). Radially, it is highly concentrated in the cambial zone and gradually decreases toward maturing xylem and phloem (Sundberg et al. 2000). It is reported that the complex interaction of diverse transport 
streams of IAA is regulated by developmental factors, but there is a profound effect of environmental factors, too (Schrader et al. 2003).

In pines, IAA follows the main transport path through the cambial zone; in other species, it flows through parenchymatic cells of the phloem as well (Uggla et al. 1996, 1998, Tuominen et al. 1997, Sundberg et al. 2000). Larson (1964) examined the system of earlywood (EW) tracheid formation in Pinus resinosa (Aiton) in the context of hormonal activity in cooperation with tree-ring formation. EW is formed at the beginning of the growing season, when annual shoots grow and lignify and IAA concentration is high. In contrast, latewood (LW) tracheids start forming at times when the intensity of IAA supply to cambium is reduced and the formation of annual shoots has ended. LW tissues have smaller radial dimensions, but thicker cell walls (Little \& Savidge 1987), and, forming at the time of reduced IAA concentration, have smaller radial dimensions; on the other hand, they have more time for differentiation and are much more intensely supplied with assimilates from already-formed annual shoots for the creation of their secondary walls, which gives them their typical thick-walled structures (Sundberg et al. 1987, Funada et al. 2001). According to Larson (1969), the formation of LW occurs when the concentration of IAA is gradually reduced and carbohydrate contents rise. The correlation between IAA concentration and formation of LW in Pinus sylvestris (L.) has not been sufficiently demonstrated (Uggla et al. 2001). Furthermore, although the IAA concentration gradient has been demonstrated by spectrophotometry in xylem tissues, the effect of IAA concentrations on individual cell elements in terms of their function (vessels, tracheids, libriform fibres, etc.) has not been specified sufficiently (Bhalerao \& Fischer 2014). Wodzicki (1971) observed the dependence of IAA concentration on radial growth and tracheid maturation during the growing season and measured a high concentration of IAA throughout June and early July. He fitted the data with an interpolation curve for correlation with tracheid differentiation,

Tab. 1 - Long-term weather data (19012014) at the study area. (T): air temperature; $(\mathrm{P})$ : precipitation.

\begin{tabular}{lc}
\hline Parameter & Value \\
\hline Average annual $\mathrm{T}\left({ }^{\circ} \mathrm{C}\right)$ & 8.1 \\
\hline Average annual total $\mathrm{P}(\mathrm{mm})$ & 601 \\
\hline Warmest month $\mathrm{T}\left({ }^{\circ} \mathrm{C}\right)$ & July \\
& $(18.1)$ \\
\hline Coldest month $\mathrm{T}\left({ }^{\circ} \mathrm{C}\right)$ & January \\
& $(-2.7)$ \\
\hline Lowest total $\mathrm{P}(\mathrm{mm})$ & February \\
& $(27.5)$ \\
\hline Highest total $\mathrm{P}(\mathrm{mm})$ & July \\
& $(82)$ \\
\hline
\end{tabular}

but he was unable to confirm a significant relationship between IAA concentration, cell enlargement and xylem cell maturation. Rather, he stressed the effect of IAA on the phenology of cambium within the cytokinetic process during the meristematic stage (production of daughter xylem cells).

Previous studies report that the ratio between IAA and soluble carbohydrates affects the type of differentiation of meristematic cells into xylem and phloem tissues (Wetmore \& Rier 1963, Jeffs \& Northcote 1966). Additionally, the radial increment of woody plants is significantly affected by the intensity of the supply and accumulation of carbohydrates, specifically, nonstructural carbohydrates. These are distributed as products of photosynthesis by phloem cells from the assimilation area to the roots. The rate of carbohydrate supply is directly associated with the phenologic cycles of woody plant assimilation organs (budding, leafing, yellowing - Suzuki et al. 1996). Currently, the effect of global warming and associated climate change has manifested. As a result of the increasing frequency of extreme hot spells arising from a high number of tropical days without precipitation, phenological stages tend to change (Christensen et al. 2007). This effect later leads to a reduction of assimilation area (foliage), and thus a reduction of the content of carbohydrates in assimilation transport. Generally, there is a reduced supply to cellular tissues, which causes inhibited meristematic functions and thus, reduced increments of woody plants and their total production (Suzuki et al. 1996). Therefore, it is advisable to focus on monitoring of specific climatic factors that influence the cycle and allocation of nutrients regarding biomass formation and quality of plant tissues. Based on these findings only, it will be possible to assess which specific types of cells are formed and under which conditions in order to achieve the desired properties of wood production.

The main objective of this preliminary study was to monitor the dynamics of indole-3-acetic acid (IAA) concentration and the amount of soluble carbohydrates in Scots pine (Pinus sylvestris L.) during one growing season (2015) under the prism of the xylogenesis and phloemogenesis processes (cambial activity, stages of xylem and phloem cell differentiation and morphometric parameters of xylem and phloem cells).

\section{Material and methods}

\section{Study area and weather conditions}

The samples for this study were taken in the territory of the School Forest Enterprise Masaryk Forest Krtiny, a research site in Sobešice, Czech Republic $\left(49^{\circ} 15^{\prime} \mathrm{N}, 16^{\circ}\right.$ $36^{\prime} \mathrm{E}, 404 \mathrm{~m}$ a.s.l.). According to long-term weather data (1901-2014), the warmest and wettest month at the site is usually July.
Tab. 1 provides a short overview of the prevailing weather conditions at the site for more than one century (Climate Research Unit Time Series, CRU TS3.23 - http://clim exp.knmi.nl).

Air temperature (Minikin TRH, EMS Brno, Czech Republic), precipitation totals (MetOne Instruments, Grants Pass, Oregon, USA) and soil water potential were continuously monitored at the site. Soil water potential was measured at depths of 15, 50, and $90 \mathrm{~cm}$, with two repeated measurements at each depth (GB1, Delmhorst Inc., Towaco, NJ, USA attached to datalogger SP3, EMS Brno, Czech Republic). In addition, the sum of effective temperatures $\left(\Sigma_{\mathrm{ET}}\right)$ was calculated for each day. The sum of the effective temperature was calculated as the sum of the mean daytime temperature for the stated periods. The threshold temperature was $5{ }^{\circ} \mathrm{C}$, with values below that counted as zero.

\section{Sample collection and preparation}

For this study, 6 sample trees of pine, 80 year-old on average, were selected. The average height of the sample trees was $25 \mathrm{~m}$, and the average stem diameter at breast height (130 cm above ground level) was 36 $\pm 7 \mathrm{~cm}$. Cell formation was monitored by regular sampling of microcores (thickness: $1.8 \mathrm{~mm}$ ) from tree stems using a Trephor increment borer (Rossi et al. 2006) at breast height at weekly intervals. Each week, 6 microcores and 6 reserve microcores were taken so that permanent microscope slides could be made. Microcores were immediately put in FAA fixing solution ( $90 \mathrm{ml} 70 \%$ ethanol, $5 \mathrm{ml} 100 \%$ glacial acetic acid, $5 \mathrm{ml} \mathrm{36-38 \%} \mathrm{formaldehyde)} \mathrm{for}$ a period of one week, then rinsed in water and stored in $50 \%$ ethanol. The microcores were then dehydrated in an ethanol series (70, 90, 95, and 100\%) and impregnated with paraffin wax ( 4 hours) in a tissue processor (Leica TP1020). Next, paraffin blocks were produced (using a Leica dispenser EG1120) in order to adapt them for a rotary microtome (Leica RM2235). The finished microsections (8-12 $\mu \mathrm{m}$ thick) were dried in a laboratory oven $\left(70{ }^{\circ} \mathrm{C}\right.$ for $\left.20 \mathrm{~min}\right)$. This was followed by selective staining with safranin and astra blue, so that lignified and non-lignified tissues could be distinguished. Further, permanent microscopic slides were made out of these microsections (Gričar et al. 2014).

To analyse the amount of IAA, 6 microcores and 6 reserve microcores were taken for spectrophotometric determination of IAA content. These microcores were stored in glass vials with $1 \mathrm{ml} 100 \%$ methanol. Microcores were extracted in $1 \mathrm{ml} 100 \%$ methanol at three stages: (1) shaker used for $15 \mathrm{~min}$ (100 rpm at laboratory temperature); (2) sonication in an ultrasonic bath (30 min at $10{ }^{\circ} \mathrm{C}$, cooled by ice); and (3) shaker used for $15 \mathrm{~min}$ (100 rpm at laboratory temperature). The entire volume of each extract was used for determination of IAA content. The methanolic extracts were 
transferred to test tubes, and samples were evaporated to dryness in a nitrogen stream. Demineralized water $(2 \mathrm{ml})$ was added to the wood mass extract evaporations in each tube. After a 10 min relaxation period, the samples in the tubes were properly mixed by vortexer, and $2 \mathrm{ml}$ Salkowski reagent $(50 \mathrm{ml} 35 \%$ perchloric acid with $1 \mathrm{ml} 0.5 \mathrm{M}$ ferric chloride solution) were added. The mixtures were mixed again by vortexer, and after a three-minute response time, the samples were analysed (absorbance of each sample was measured, limit of amount measurability $-2 \mu \mathrm{g}$ sample $^{-1}$ ) in a METASH $5100 \mathrm{~V}$ spectrophotometer at a wavelength of $530 \mathrm{~nm}$ and compared with demineralized water (Fu et al. 2011, Nakurte et al. 2012, Podlešáková et al. 2012).

The extraction procedure for determination of soluble carbohydrates was based on a similar principle, except that at the second stage, sonication was carried out at a temperature of $60^{\circ} \mathrm{C}$. Then, $1 \mathrm{ml}$ demineralized water and $1 \mathrm{ml} 5 \%$ fresh phenol solution were added to methanolic extracts of wood mass in each tube, and the mixtures were mixed by vortexer. Next, $5 \mathrm{ml}$ concentrated sulphuric acid were immediately added, and the mixtures were mixed manually and left to stand for $10 \mathrm{~min}$. After this time, the samples were properly mixed by vortexer and allowed to continue the reactions in a thermostatic water bath at a temperature of $22-23{ }^{\circ} \mathrm{C}$ for $30 \mathrm{~min}$. After the reaction time, the samples were analysed (absorbances were measured) using a METASH $5100 \mathrm{~V}$ spectrophotometer at a wavelength of $490 \mathrm{~nm}$ and compared with demineralized water. The resulting values based on standardisation are given in the amount of glucose per sample ( $\mu$ g GLU sample ${ }^{-1}$ - Albalasmeh et al. 2013).

\section{Measurements and data processing}

To analyse permanent microscope slides, we used a Leica DMLS light microscope with a Leica DFC 280 digital camera and ImageJ software (Abramoff et al. 2004). Cambial activity, differentiation and morphology of xylem and phloem cells (cambial activity, stages of xylem and phloem cell differentiation, and morphometric parameters of xylem and phloem cells) were analysed in the radial direction of the crosssections of the microscope slides. The number of cells in the cambium zone (thinwalled and radially flattened rectangular cells) and the number of cells at various stages of differentiation during the whole growing season were explored. Cells at the stage of cell enlargement (post-cambial cells, PC) were differentiated from cambial cells based on their radial dimensions, which are at least twice as large. The stage of secondary cell thickening (SW) was distinguished from the PC stage by the polarizing filter; cell walls with parallel microfibrils reflected the same angles of light, which manifested as a distinguishing boundary of shiny cells under this filter
(Deslauriers et al. 2008). Cell walls of matured tracheids (MT) were fully coloured with red safranin. Further, early phloem sieve cells were analysed. Early phloem (EP) sieve cells were identified in the same way as the cells at the PC stage, as their radial dimensions were at least double compared with cambial cells. Late phloem (LP) sieve cells were separated from EP cells by a boundary of axial parenchyma (AP), which looks like a strip of cells with redcoloured lumina dyed by safranin.

The intensity of radial cellular growth was determined using the Gompertz function mathematical model (Rossi et al. 2003). The input parameters for this function were the actual measured data of the total weekly cell increments. The growth sigmoid curve demonstrates the total value of the radial increment, and the curve of the first derivative shows the rate of radial growth value for the period (growth intensity). Due to variability of the number of cells around the stem circumference, it was necessary to define the increment trend with this function in order to avoid a decrease in the cumulative value of cell radial growth. This function fitted the real values to its model curve and so defined the course of growth by the equation (eqn. 1):

$$
y=A e^{-e(\beta-\kappa t)}
$$

where $y$ is the cumulative value of the number of cells in one week, $t$ is the day of the year, $A$ is the upper asymptote of the maximum number of cells, $\beta$ is the parameter location on the $\mathrm{x}$-axis, $\kappa$ is the inflection point on the curve representing the maximum daily increment of cells.
Measurement of morphological parameters of xylem and phloem

Morphometric parameters of cells within the last formed tree ring were analysed. In each of these tree rings, three radial rows of xylem and phloem cells were selected, and the following parameters were measured in each of the selected rows: cell wall thickness, radial dimension of cell lumen, total cell radial dimension, and total number of cells formed (Gričar et al. 2015). Mork's criterion was used to differentiate EW from LW xylem. If twice the double cell wall in a tracheid was larger than the cell lumen, that cell was recorded as LW (Denne 1989). To determine thickness of cell walls, the dimensions of the double cell wall (thickness of two adjacent cell walls) were measured in that particular row of cells. Total radial dimensions of cells were calculated by the formula (eqn. 2):

$$
R=\frac{1}{2}(2 C W)+L+\frac{1}{2}(2 C W)
$$

where $R$ is the total cell radial dimension, $2 \mathrm{CW}$ is the thickness of double cell wall, $L$ is the cell lumen width.

\section{Results}

\section{Weather data}

In 2015, the average annual air temperature was $10.0{ }^{\circ} \mathrm{C}$. The coldest month was February $\left(0.7^{\circ} \mathrm{C}\right)$, and the warmest month was August $\left(22.4{ }^{\circ} \mathrm{C}\right.$ on average). The highest precipitation total, $69.6 \mathrm{~mm}$, was also recorded in August; however, $50.8 \mathrm{~mm}$ was recorded on just a single day (August 18; day of the year, DOY: 230). The driest month was April with just $6.2 \mathrm{~mm}$ of pre-

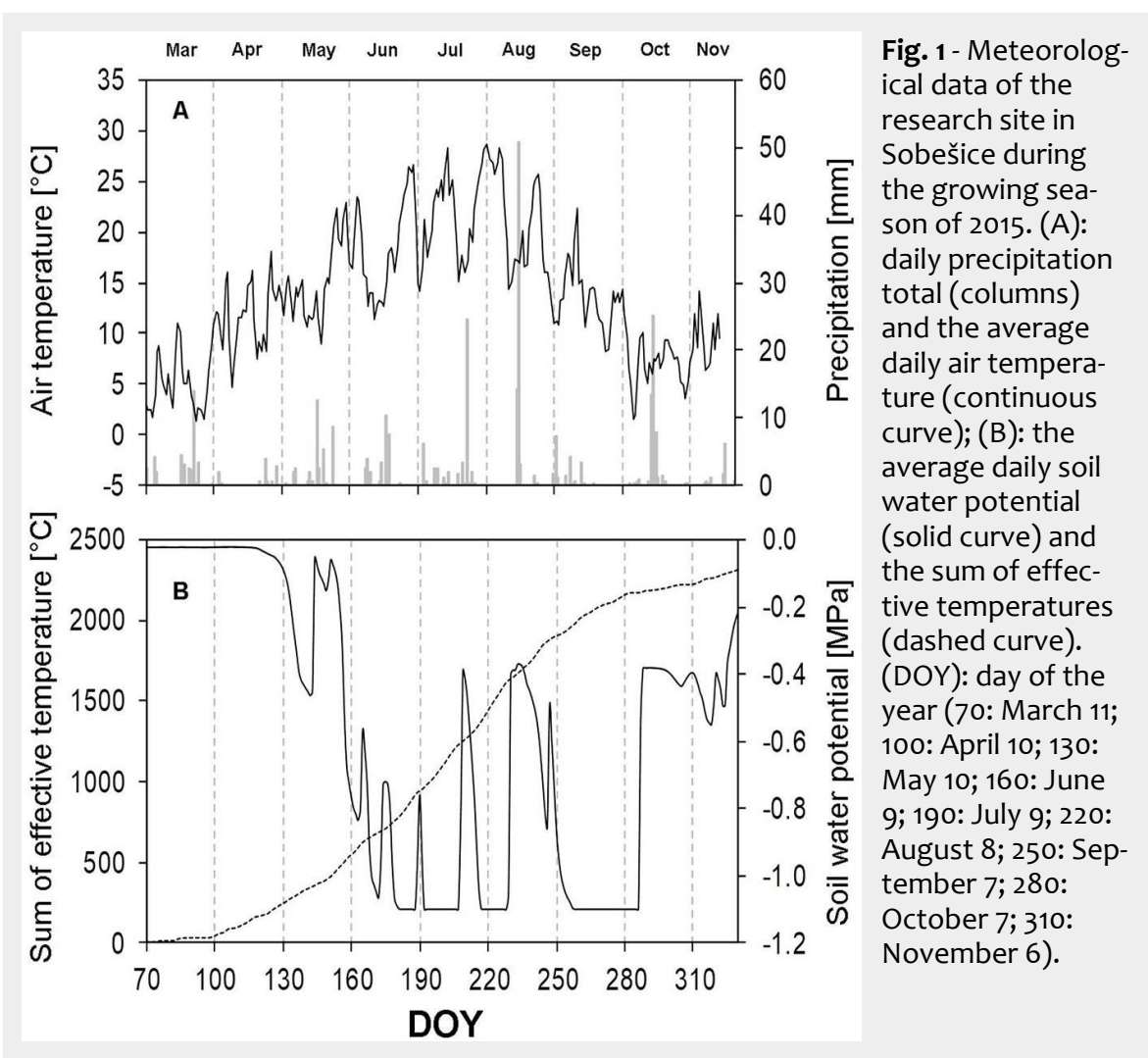


Tab. 2 - The timing of particular stages of cell formation of xylem and phloem. (CA): beginning of cambial activity; (CCA): end of cambial activity; (PC): beginning of cell enlargement; (CPC): end of PC; (SW): beginning of secondary cell thickening; (CSW): end of SW; (MT): occurrence of the first fully matured tracheids; (EP): beginning of formation of sieve cells of early phloem; (LP): beginning of formation of sieve cells of late phloem (at the same time ending of EP); (CLP): end of LP and phloem formation generally. The values stand for day of year (DOY) \pm standard deviation.

\begin{tabular}{lcc}
\hline Parameters & Xylem & Phloem \\
\hline Beginning of cambial activity - CA & $90 \pm 9$ & $90 \pm 9$ \\
Beginning of formation of sieve cells of early phloem - EP & - & $92 \pm 8$ \\
Beginning of cell enlargement - PC & $108 \pm 7$ & - \\
Beginning of secondary cell thickening - SW & $122 \pm 4$ & - \\
Beginning of formation of sieve cells of late phloem - LP & - & $128 \pm 5$ \\
Occurrence of the first fully developed tracheids - MT & $138 \pm 7$ & - \\
End of LP and phloem formation - CLP & - & $175 \pm 5$ \\
End of cambial activity - CCA & $189 \pm 10$ & $226 \pm 7$ \\
End of cell enlargement - CPC & $194 \pm 10$ & - \\
End of secondary cell thickening - CSW & $265 \pm 27$ & - \\
CA - stage duration (number of days) & $99 \pm 15$ & $99 \pm 15$ \\
PC - stage duration (number of days) & $85 \pm 9$ & - \\
SW - stage duration (number of days) & $142 \pm 26$ & - \\
EP - stage duration (number of days) & - & $36 \pm 5$ \\
LP - stage duration (number of days) & - & $47 \pm 10$ \\
\hline
\end{tabular}

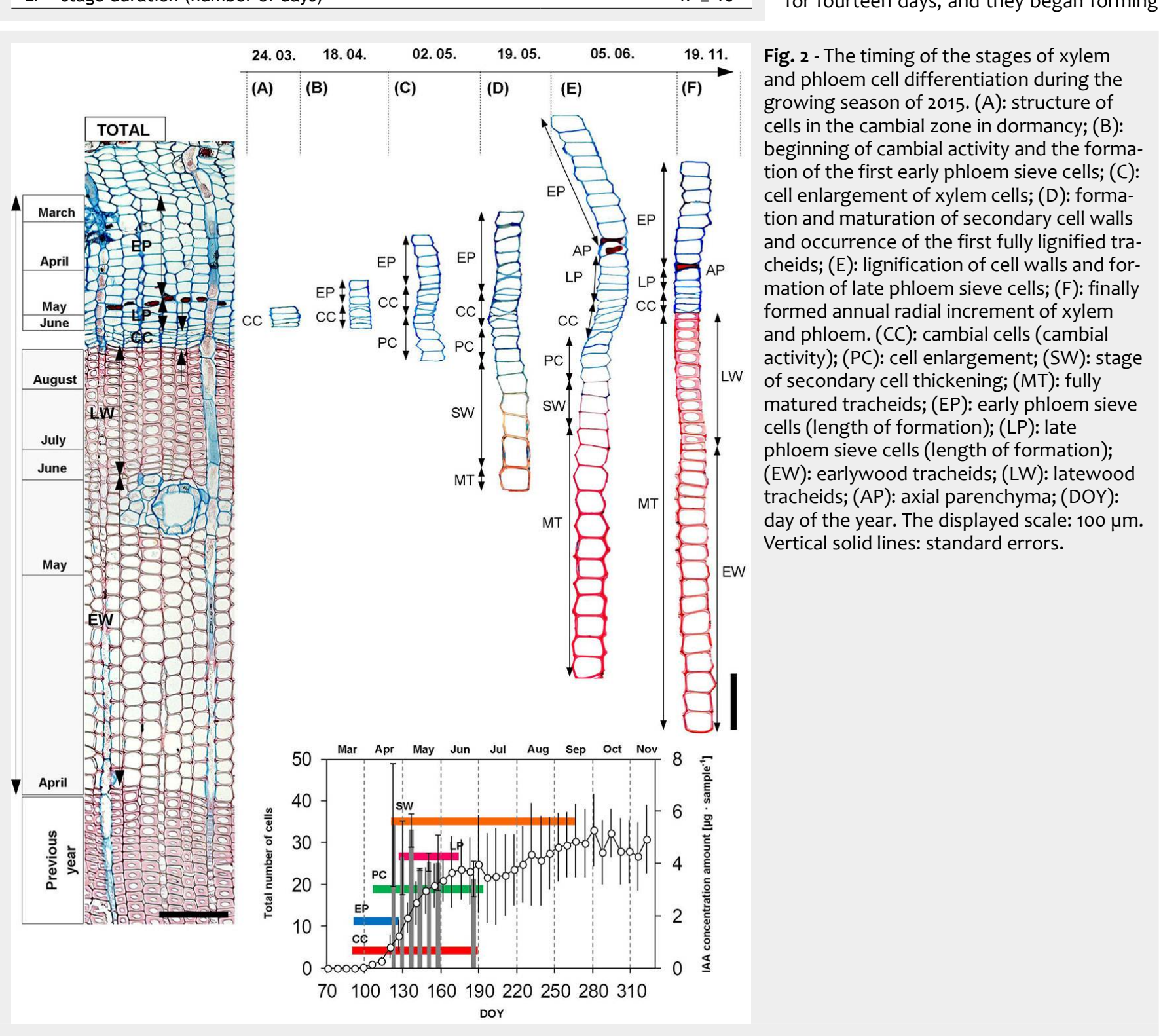

cipitation. These fluctuations are reflected in the graph of soil water potential (Fig. $1 \mathrm{~B})$, showing steep local increases during the dry period without rainfall. This effect can be seen especially in the summer, when the soil water potential values fluctuated from -1.1 to -0.4 MPa. The total annual precipitation was $405.6 \mathrm{~mm}$, which is approximately $33 \%$ less compared to the longterm mean.

\section{Dynamics of xylogenesis and phloemogenesis}

Before the start of the 2015 growing season (at the time of dormancy), the cambial zone contained $5.4 \pm 0.8$ cells (DOY: 71 , March 12). The onset of cambial activity, as defined by the number of cambial cells, was detected on March 31 (DOY: $90 \pm 9, \Sigma_{\mathrm{ET}}$ $=30.72{ }^{\circ} \mathrm{C}$ ). While the beginning of EP formation was observed on April 2 (DOY: $92 \pm$ 8 ), the first xylem cells at the PC stage were observed over 14 days later (DOY: 108 \pm 7 - Tab. 2), when the sum of effective temperatures was $89.39{ }^{\circ} \mathrm{C}$ (see Fig. 1B). These cells grew into their final dimensions for fourteen days, and they began forming and phloem cell differentiation during the beginning of cambial activity and the formation of the first early phloem sieve cells; (C): cheids; (E): lignification of cell walls and formation of late phloem sieve cells; (F): finally activity); (PC): cell enlargement; (SW): stage of secondary cell thickening; (MT): fully matured tracheids; (EP): early phloem sieve cells (length of formation); (LP): late phloem sieve cells (length of formation); tracheids; (AP): axial parenchyma; (DOY): day of the year. The displayed scale: $100 \mu \mathrm{m}$. Vertical solid lines: standard errors. 
secondary cell walls in the first week of May (Tab. 2, Fig. 2). Additionally, intensity of cambial division was highest during the first week of May, and the maximum number of cells in the cambial zone $(10.9 \pm 1.8)$ was detected. Moreover, the beginning of the formation of LP was detected in this period (DOY: $128 \pm 5$, May 8 ). The first lignified (fully mature) EW cells were observed in the course of the following week. Phloem cell formation ended on June 24 (DOY: 175), when the number of CC cells dropped to $6.9 \pm 1.3$. It was found that cambial activity ceased on DOY $189 \pm 10$, less than a week before the end of the PC stage. Thus, the number of cambial cells in the second week of July was identical to their number in the dormant period. All tracheids had fully lignified cell walls by the beginning of October (DOY: $265 \pm 27$ ).

Auxin (IAA) activity - concentration of soluble carbohydrates

In the course of the 2015 growing season, the concentration of IAA was observed in interaction with the duration and intensity of formation of individual types of the secondary phloem and xylem cells. The highest concentration of IAA (according to sample absorbances) was measured in the last week of April (Fig. 3, Fig. 4). The values decreased gradually in the following month, and in the second week of June, the concentration rapidly decreased below the limit of measurability ( $2 \mu \mathrm{g}$ sample $\left.{ }^{-1}\right)$. At the time when the highest concentration of IAA was measured, we also detected the maximum number of cells in the cambial zone (Fig. 3A, Fig. 4A) and the highest expansion of cells in the PC stage (Fig. $3 C$ ). The last measurable values of IAA concentration were found on July 2 (DOY: $183,3.4$ $\pm 0.7 \mu \mathrm{g}$ sample $\left.^{-1}\right)$. Further, the IAA concentrations ranged below the limit of measurability. The formation of LW started in this period, and LP formation stopped.

The first significant increase in concentration of soluble carbohydrates was recorded on March 26 (DOY: 85), with a measured value of $123.04 \pm 0.5 \mu \mathrm{g}$ GLU sample ${ }^{-1}$. Concentrations increased significantly during April, culminating in the second week of May (by increasing $110 \%$ compared to the dormant period). The highest concentration of soluble carbohydrates was measured on May 14 (DOY: 134; $200.40 \pm 21.6$ $\mu g$ GLU sample-1). Thus, this occurred two weeks later than when the maximum value of IAA concentration was measured. From the beginning of June, it was possible to observe a gradual decrease in the concentration of soluble carbohydrates. In the last week of August, the concentration of carbohydrates was at a level similar to the beginning of the growing season. At the time when the maximum concentration of soluble carbohydrates was found, the fastest weekly xylem cell increment was established by using the Gompertz function (Fig. 5). This effect was not observed for phloem. The amount of soluble carbohy-
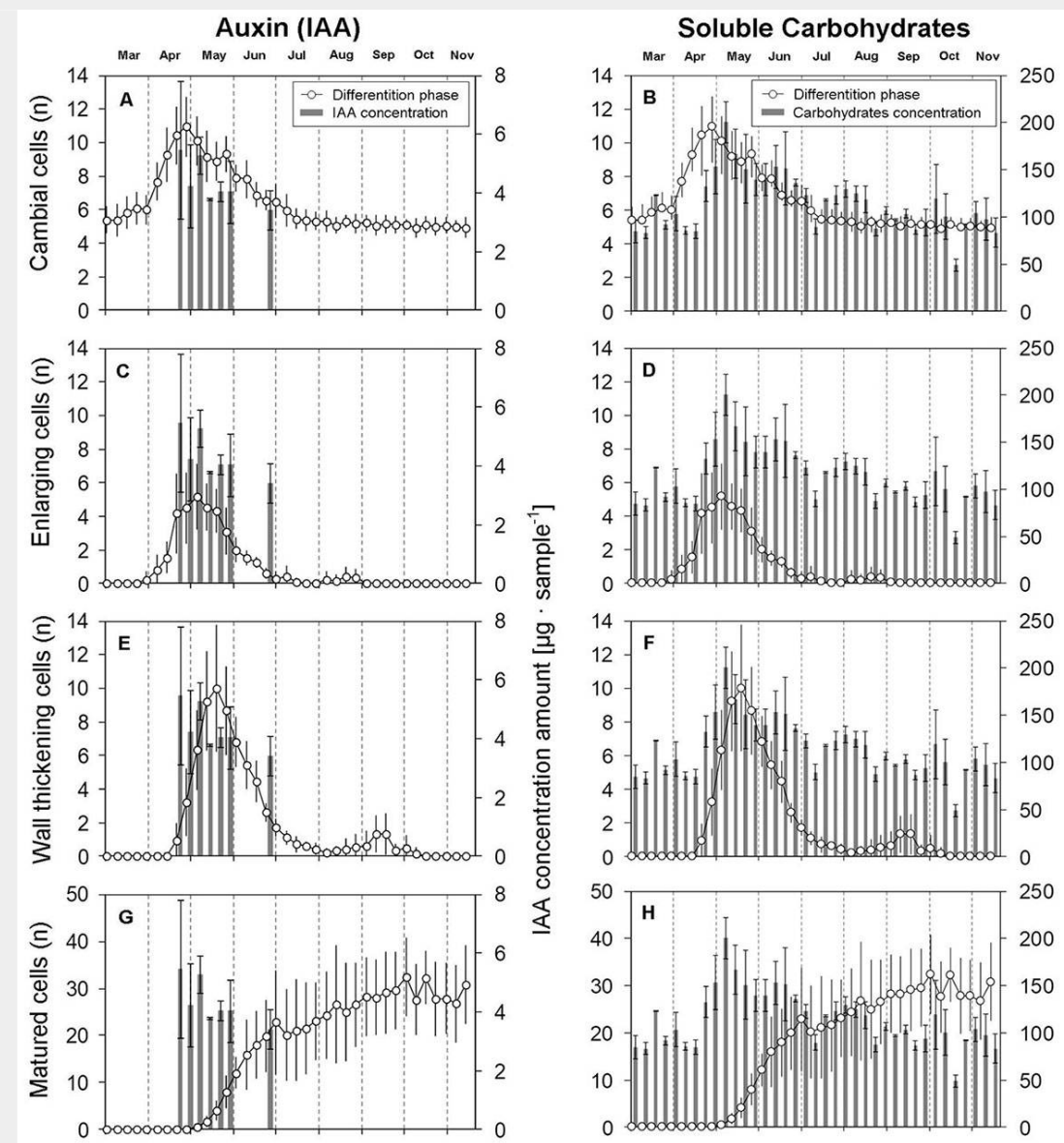

Fig. 3 - Dynamics of xylem cell differentiation in relation to indole-3-acetic acid (IAA) and soluble carbohydrate concentrations during the growing season 2015. (n): the number of cells at the stage; (DOY): day of the year (70: March 11; 100: April 10; 130: May 10; 160: June 9; 190: July 9; 220: August 8; 250: September 7; 280: October 7; 310: November 6). Vertical solid lines: standard errors.

drates therefore affected the intensity of xylem cell formation (Fig. 3 F, Fig. $3 \mathrm{H}$ ).

\section{Gompertz function}

We found that the average total radial increment was formed by 28.33 xylem cells and 8.91 phloem cells (Tab. 3). This annual

Tab. 3 - Parameters of the Gompertz function for xylem and phloem cells for the year 2015 (number of cells).

\begin{tabular}{lrr}
\hline Parameters & Xylem & Phloem \\
\hline Total number of cells & 28.33 & 8.91 \\
Daily cell rate & 0.25 & 0.12 \\
Maximum of daily cell rate & 0.36 & 0.17 \\
Day of maximal daily cell rate (DOY) & 132.23 & 108.32 \\
Number of days for fully formed cell increment & 114.28 & 76.31 \\
Coefficient of determination $\left(\mathrm{R}^{2}\right)$ & 0.70 & 0.87 \\
\hline
\end{tabular}



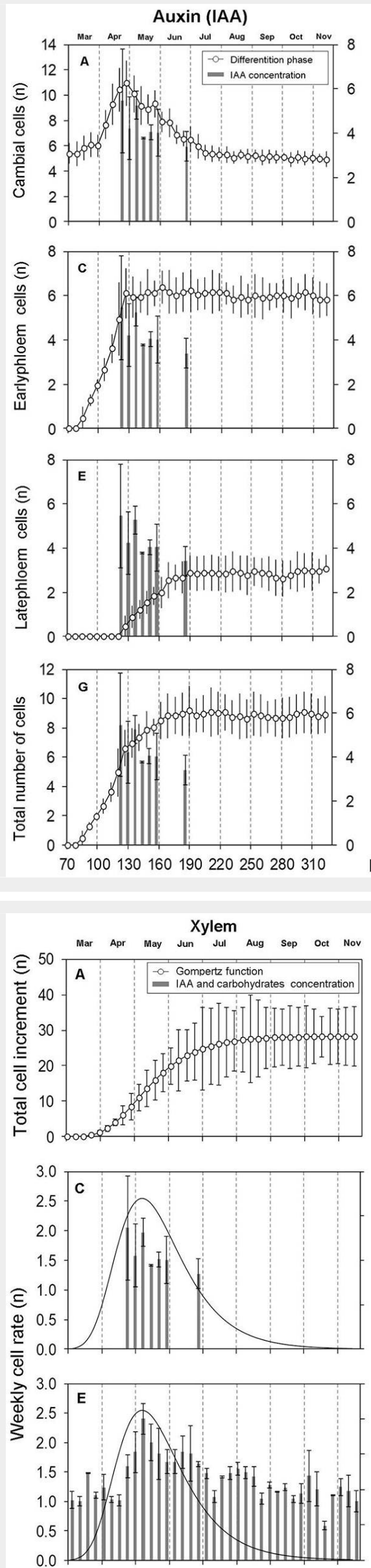

$\begin{array}{lllllllll}70 & 100 & 130 & 160 & 190 & 220 & 250 & 280 & 310\end{array}$
Soluble carbohydrates
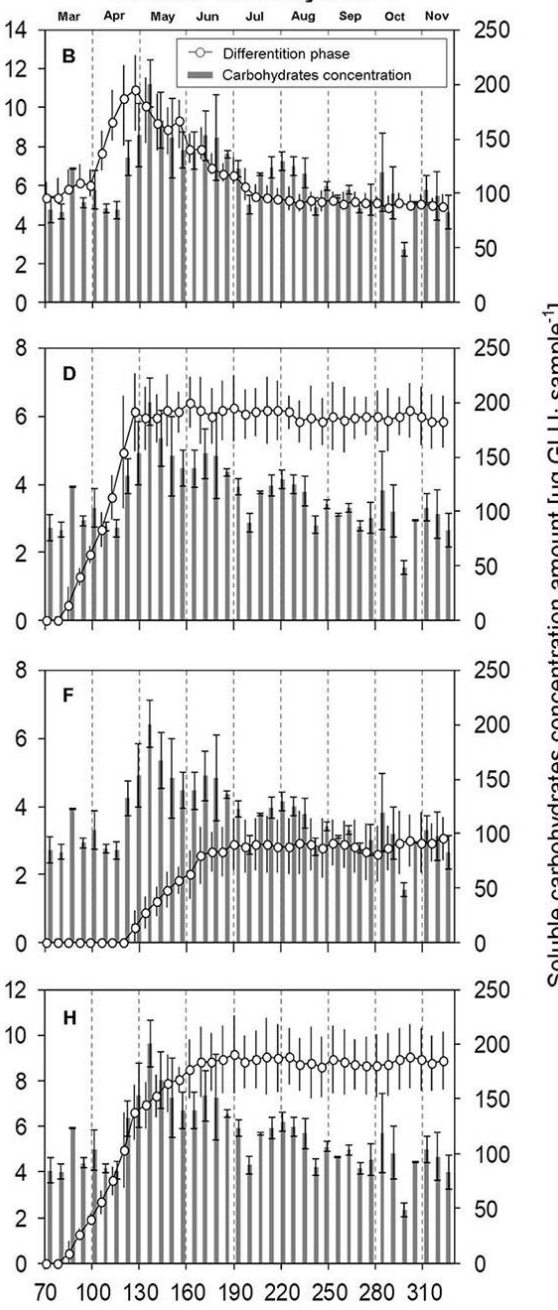

Fig. 4 - Dynamics of phloem cell differentiation in relation to indole-3-acetic acid (IAA) and soluble carbohydrate concentrations during the growing season 2015. (n): the number of cells at the stage; (DOY): day of the year (70: March 11; 100: April 10; 130: May 10; 160: June 9; 190: July 9; 220: August 8; 250: September 7; 280: - October 7; 310: November 6). Vertical 응 solid lines: standard errors.
Fig. 5 - Intensity of cell increment defined by the Gompertz function in relation to auxin and soluble carbohydrate concentrations during the growing season 2015. (A, B): growth S-curve of the Gompertz function; (C, $D, E, F)$ : curve of the first derivation demonstrating the intensity of oneweek increment. ( $n$ ): the number of cells at the stage; (DOY): day of the year (70: March 11; 100: April 10; 130: May 10; 160: June 9; 190: July 9; 220: August 8; 250: September 7; 280: October 7; 310: November 6). Vertical solid lines: standard errors. 
intensity of xylem formation ( 0.36 cells day $^{-1} ; 2.54$ week $^{-1}$ ). The maximum cell increment of phloem cells was detected on April 18 (DOY: 108 - Fig. 5D, Fig. 5F), when it was 0.17 cells day $^{-1}\left(1.19\right.$ cells week $\left.{ }^{-1}\right)$. A fully lignified tree ring was formed in 114.28 days, and the total annual phloem increment was formed in 76.31 days (Tab. 3). In the case of phloem, Fig. 5B shows that the standard deviations of the Gompertz function values demonstrated minimum variabilities compared to xylem cells (Fig. 5A).

\section{Morphometric parameters of xylem and phloem cells}

\section{Xylem cells}

The dynamics of cell growth in terms of the morphometric parameters of cells at a given time was monitored during the 2015 growing season (Tab. 4, Fig. 6). As shown in Fig. $6 \mathrm{~A}$ and Fig. $6 \mathrm{C}$, a characteristic trend of radial dimensions of EW and LW was demonstrated, in which first thin-walled EW with more than twice as large radial dimensions compared to LW were formed at the beginning of the growing season. In contrast, in the summer (first half of July), thick-walled LW tissues with significantly smaller radial dimensions were formed. Fig. 6C shows how the thickness of the double cell walls of tracheids gradually grew during the growing season and culminated in the LW formation period. When cambial activity gradually ceased, the thickness of the double cell walls nearly matched tracheid dimensions at the beginning of the growing season. Fig. 6 shows that the thick-walled LW began forming late in the period when IAA concentration dropped below the limit of measurability $(2 \mu \mathrm{g}$ sam$\left.\mathrm{ple}^{-1}\right)$. Furthermore, the values of tracheid radial size decreased along with the values of IAA concentration.

\section{Phloem cells}

While a significant difference $\left(R^{2}=0.824\right)$ in radial dimensions of cells in terms of their growth period (as well as in terms of their positions within a tree ring) was proved in EW and LW, there was no significant statistical difference $\left(R^{2}=0.002\right)$ between the two cell types in the case of phloem cells (EP and LP), which is confirmed by the graphs in Fig. 6B and Fig. 6D. At the same time, these graphs demonstrate that the number of EP cells was up to three times greater than the number of LP cells. When the highest IAA concentration was found, the formation of LP cells started. Additionally, the value of the content of soluble carbohydrates sharply increased by more than $110 \%$ in this period (Fig. 6F, Fig. 6H). Phloem cells were formed in a substantially shorter time, and their formation stopped at a time when LW did not begin forming.

\section{Discussion}

These results prove that IAA and the amount of soluble carbohydrates affect
Tab. 4 - Descriptive statistics of morphometric parameters of xylem and phloem cells. (EW): earlywood tracheids; (LW): latewood tracheids; (EP): sieve cells of early phloem; (LP): sieve cells of late phloem; $(\mathrm{N})$ : number of values measured; (SD): standard deviation. Units used: $\mu \mathrm{m}$.

\begin{tabular}{llllrrrrc}
\hline Tissue & Type & Cell Parameters & N & Average & Min & Max & SD & $\begin{array}{c}\text { Var. } \\
\text { coeff. }\end{array}$ \\
\hline Xylem & EW & Radial dimension & 320 & 37.2 & 16.0 & 64.3 & 8.8 & 23.7 \\
& & Lumen dimension & 320 & 32.8 & 10.6 & 60.1 & 9.0 & 27.4 \\
& & Double cell wall & 320 & 4.4 & 2.2 & 7.8 & 1.0 & 21.9 \\
\cline { 2 - 8 } & LW & Radial dimension & 117 & 14.5 & 6.6 & 27.5 & 3.9 & 26.7 \\
& & Lumen dimension & 117 & 8.9 & 2.6 & 22.6 & 3.5 & 39.5 \\
& & Double cell wall & 116 & 5.4 & 2.6 & 9.7 & 1.6 & 28.8 \\
\hline \multirow{2}{*}{ Phloem } & EP & Radial dimension & 118 & 21.4 & 11.1 & 40.7 & 5.3 & 24.9 \\
& & Lumen dimension & 118 & 19.9 & 9.6 & 39.2 & 5.4 & 27.1 \\
& & Double cell wall & 118 & 1.5 & 0.8 & 2.5 & 0.3 & 21.6 \\
\cline { 2 - 8 } & LP & Radial dimension & 42 & 21.6 & 11.0 & 32.7 & 5.5 & 25.5 \\
& Lumen dimension & 42 & 20.0 & 9.9 & 31.1 & 5.5 & 27.4 \\
& Double cell wall & 42 & 1.5 & 0.9 & 2.0 & 0.3 & 19.2 \\
\hline
\end{tabular}
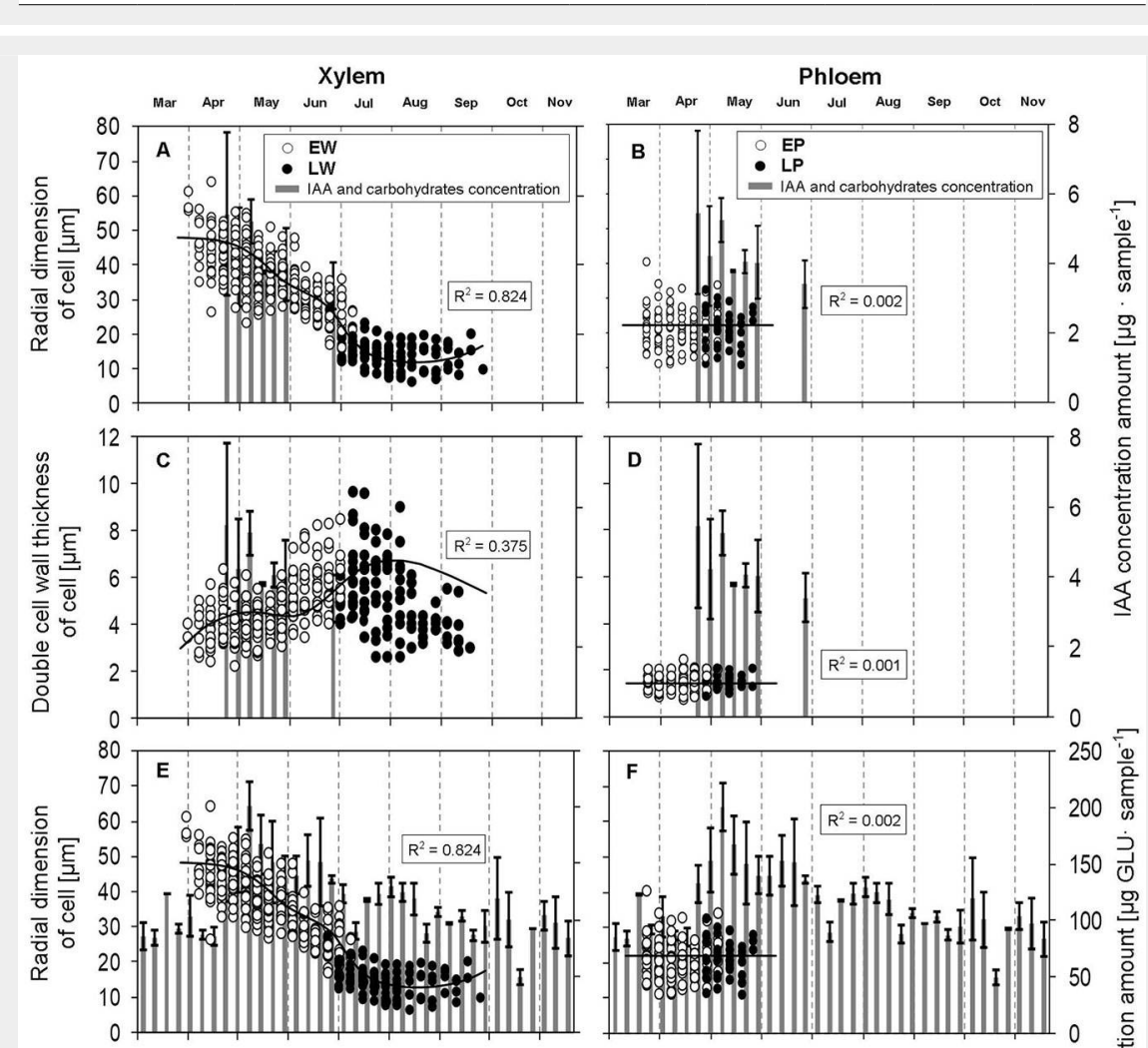

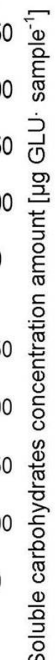
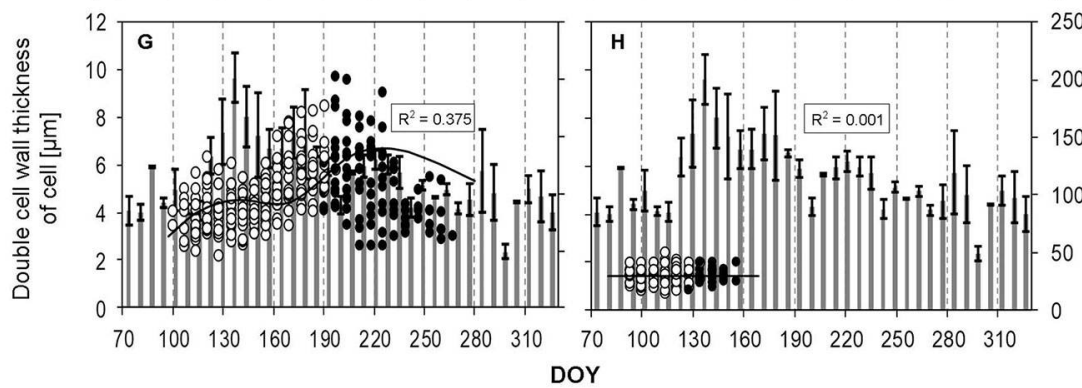

Fig. 6 - Morphometric parameters of xylem and phloem cells formed in relation to the concentration of indole-3-acetic acid (IAA - A, B, C, D) and soluble carbohydrates ( $E$, $F, G, H$ ) during the growing season 2015. $\left(R^{2}\right)$ : coefficient of determination; (EW): earlywood tracheids; (LW): latewood tracheids; (EP): early phloem sieve cells; (LP): late phloem sieve cells; (DOY): day of the year (70: March 11; 100: April 10; 130: May 10; 160: June 9; 190: July 9; 220: August 8; 250: September 7; 280: October 7; 310: November $6)$. Vertical solid lines: standard errors. 
cambial activity and the dynamics of xylem and phloem cell formation. This interdependence manifests most in the sequence of the onset of individual differentiation stages, rather than in the duration of each specific stage. However, highly adverse weather conditions during summer played an important role in this study. An excep tionally dry period in late July and throughout August resulted in an early termination of cambial activity. As weather charts de picted, no precipitation was recorded for full three weeks in August when the temperatures exceeded a mean value of $26^{\circ} \mathrm{C}$ (the warmest period in the year). This exceptionally dry period is also confirmed by the soil water potential values (over -0.4 $\mathrm{MPa}$ ). This factor significantly affected the lengths of cell formation stages and thus the total number of cells in xylem (treering width). Additionally, it affected the number of cells in LW and the total ratio of EW and LW in the annual radial increment. The formation of phloem cells ended before this dry period.

The number of cambial cells showed that in the period of maximum cambial activity, the strongest expansion of the cell enlargement stage was observed. In the same period, IAA concentrations reached the highest values. This coincided with the findings of Wodzicki (1971) on IAA concentration in Pinus sylvestris L. (Poland). Sundberg et al. (2000), as well as Bhalerao \& Bennett (2003), stated that the highest IAA concentration was located in the cambia zone and was most involved in cell division, suggesting that cell enlargement was sup ported at lower concentrations and, at the same time that IAA was involved in the initiation of cell secondary thickening at a lower intensity. Our findings also demonstrate that when the maximum IAA concentration was detected, EW thin-walled tracheids with larger radial dimensions were formed. At the same time, maximum cambial activity (the highest number of cells in the cambial zone) was observed in this period. Carlsbecker \& Helariutta (2005) suggested that IAA is one of the main stim ulants for meristematic function of the cambium and, at the same time, a regulator of cells in radial growth; this was also confirmed in this study, as we recorded the greatest frequency of cells at the cell enlargement stage when the highest value of IAA concentration was detected. The same conclusion was reached by Sieburth \& Deyholos (2006). Cells formed in this period had the largest total radial dimensions. The effect of IAA on the formation and differentiation of EW in Pinus resinosa was proved by Larson (1964), who associated this effect with phenology stages of assimilation organs (growth and lignification of shoots).

According to Uggla et al. (2001), decreases in IAA concentrations had no influence on the end of cambial activity, since this is mostly controlled by environmental parameters. The amount of IAA in the cam- bial zone in the middle of summer nearly corresponded with the amount of IAA in the dormant cambium in the middle of winter. Uggla et al. (1996) analysed the IAA concentration gradient in the radial direction of tissues of formed annual increment, observing the most intense IAA concentrations during the strongest expansions of xylem cells and the beginning of their secondary thickening. An increasing number of cells in the cambial zone correlates with an increasing number of xylem cells formed; thus, the number of forming xylem cells in the radial direction is not in direct correlation with the mitotic activity of cambium, but with the concentration of IAA itself (Gregory 1971, Uggla et al. 1996).

Furthermore, our results indicated that at the moment when IAA concentration started to decrease significantly, LW with significantly smaller radial dimensions and thicker cell walls started forming. Nevertheless, Uggla et al. (2001) observed that the initiation of LW formation is not a consequence of reduced IAA concentration, but it is a change in radial gradient in forming tissues, describing this phenomenon by the reduction of the distribution path in the radial direction, when the IAA is concentrated only to the area of cambium and emerging daughter cells in the meristematic stage. Hence, the formation of LW is assisted by maturing cells that are no longer in the active zone of IAA, which then only supplies the area of cambium. A sharp decrease in IAA concentration was observed at the transition between the zone of cell enlargement and cell secondary thickening; thus, LW is formed in the period with significantly restricted IAA supply (Uggla et al. 2001). However, no significant decrease in IAA concentration was observed during LW formation in our study. Contrarily, LW started to form after the period of the most intense supply of IAA and soluble carbohydrates. Based on the literature, IAA had no effect on cell maturation (Sundberg et al. 2000, Bhalerao \& Bennett 2003). Savidge (1991) reported that IAA has no direct relation to lignification during xylem formation in Larix laricina (Du Roi) K. Koch. In our study, at the point of highest IAA concentration, the stage of cell secondary thickening started, as did LP formation. It was confirmed for phloem cells that at the time with the highest values of IAA contents, LP cells had already begun to form.

Larson (1964) also stated that LW started forming only after shoots and new needles had been formed, which corresponds with the amount of allocated carbohydrates in Pinus sylvestris found in Sobešice in 2015. We found that the concentration of soluble carbohydrates culminated in Sobešice (in 2015) two weeks after maximum IAA concentration. The curve of cambial activity nearly copied the trend of the concentration of soluble carbohydrates. This effect has also been confirmed by the Gompertz function (graph of the first derivative): at the time of the maximum concentration of carbohydrates, the fastest cell increment was recorded. This was also the period when the strongest expansion (the highest number of cells) at the secondary thickening stage was observed. When Scots pine grows in temperate ecosystems, the LW tissues spend the most time at the stage of cell secondary thickening compared to EW. This also confirms the reason for the greater thickness of their cell walls. This phenomenon has been described by Sundberg et al. (1987) and Funada et al. (2001), who explain the greater thickness of LW cell walls by a higher allocation of assimilates and a longer time for formation of the secondary wall.

Xylem cell maturation is significantly influenced by the concentrations of glucose and fructose. Uggla et al. (2001) observed the highest concentration of these carbohydrates in maturing tracheids while detecting the highest content of another soluble carbohydrate, sucrose, in the area of phloem. Due to overall low seasonal variability, a momentary increase in concentrations of soluble carbohydrates was not considered to be the main stimulant for LW formation. However, it was reported as an important element affecting the vascular development of forming tissues (Uggla et al. 2001). According to Sheen et al. (1999), soluble carbohydrates are not only a source of energy for maturation of cells but also growth regulators facilitating the general interactions between plant hormones and carbohydrates.

Uggla et al. (2001) observed the highest values of soluble carbohydrate concentrations in the area of phloem. This value dropped sharply at the transition between the zones of phloem and cambium. Our findings show that the greatest intensity of phloem cell increment was demonstrated almost a month earlier than the recorded maximum increment of xylem cells. It is therefore a period of phloem cell formation, in which the secondary wall of xylem cells has not started to develop, and the concentrations of IAA and soluble carbohydrates have not reached their maxima. Therefore, most phloem cells were formed before the maximum concentration of nutrients, which confirms that phloem, which is crucial to tree survival, must be primarily formed so that nutrients can be distributed and xylem tissues formed (Evert 2006, Taiz \& Zeiger 2006).

\section{Conclusions}

Xylem and phloem formation depends on several aspects, particularly a combination of exogenous and endogenous factors, brought about by a complex of natural site conditions and genetic predisposition. Although these two tissues have different primary functions, their activities are mutually interlinked in a functional complex (Evert 2006). However, annual increment of phloem is much more significant for vitality and viability of a tree (Evert 2006, Taiz \& 
Zeiger 2006, Gričar et al. 2009). The results suggest that when IAA concentrations increased or decreased, important changes in the activity of xylem and phloem occurred, including the highest cambial activity and the beginning and end of cell formation. At the time when the highest concentrations of soluble carbohydrates were measured, significant processes of cell formation were observed (e.g., the progress of cambial activity, the occurrence of first lignified tracheids). Nevertheless, a significant drought period was demonstrated in Sobešice during 2015, which probably inhibited IAA transport. Therefore, considerable deviations in IAA concentrations occurred. This fluctuating trend influenced the cell differentiation stages. These results indicate that IAA concentration mainly affects cambial division (cytokinesis) and initiation of particular differentiation stages. Further, IAA concentration influenced length of phloem cell formation. Although it is known that IAA concentration and soluble carbohydrate values do not affect length of cambial activity and the transition from EW to LW formation, the metabolic processes of these substances affect the developmental differentiations of tissues. These processes, which affect the changes in individual differentiation stages, are thus mainly affected not by the amounts, but rather, by the changes in IAA concentration and soluble carbohydrate gradients.

\section{Acknowledgements}

This study was supported by: IGA LDF (LDF_VP_2016014), "The effect of stress on physiology, anatomy and xylem xylogenesis pine forest" PINESTRESS (LD COST CZ, No. LD13017), Project Indicators of Trees Vitality (INVID) Reg. No. CZ.1.07/2.3.00/20. 0265, European Social Fund and the state budget of the Czech Republic, Czech Globe - Global Change Research Institute of the Czech Academy of Sciences (GCRI). This work was supported by the Ministry of Education, Youth and Sports of CR within the National Sustainability Program I (NPU I), grant number LO1415. In addition, we would like to thank the "American Journal Experts" professional copy-editing service for certifying the quality of the language.

\section{References}

Abramoff MD, Magalhães PJ, Ram SJ (2004). Image processing with imagej. Biophotonics International 11: 36-42.

Albalasmeh AA, Berhe AA, Ghezzehei TA (2013). A new method for rapid determination of carbohydrate and total carbon concentrations using UV spectrophotometry. Carbohydrate Polymers 97: 253-261. - doi: 10.1016/j.carbpol.2013. 04.072

Aloni R (1995). The induction of vascular tissues by auxin and cytokinin. In: "Plant Hormones: Physiology, Biochemistry and Molecular Biology" (Davies PJ ed). Springer, Kluwer, Dordrecht, Netherlands, pp. 531-546. - doi: 10.1007/ 978-94-011-0473-9_25
Bhalerao RP, Bennett MJ (2003). The case for morphogens in plants. Nature Cell Biology 5: 939-943. - doi: 10.1038/ncb1103-939

Bhalerao RP, Fischer U (2014). Auxin gradients across wood - instructive or incidental? Physiologia Plantarum 151: 43-51. - doi: 10.1111/ppl.12 134

Carlsbecker A, Helariutta Y (2005). Phloem and xylem specification: pieces of the puzzle emerge. Current Opinion in Plant Biology 8: 512517. - doi: 10.1016/j.pbi.2005.07.001

Denne MP (1989). Definition of latewood according to Mork (1928). IAWA Journal 10: 59-62. doi: 10.1163/22941932-90001112

Christensen JH, Hewitson N, Busuioc A, Chen A, Gao X, Held I, Jones R, Kolli RK, Kwon WT, Laprise R, Magana Rueda $V$, Mearns L, Menéndez GG, Räisänen J, Rinke A, Sarr A, Whetton P (2007). Regional climate projections. In: "Climate Change 2007: the Physical Science Basis. Contribution of Working Group I to the Fourth Assessment Report of the Intergovernmental Panel on Climate Change" (Solomon S, Qin D, Manning M, Chen Z, Marquis M, Averyt KB, Tignor $M$, Miller $\mathrm{HL}$ eds). Cambridge University press, Cambridge, UK, pp. 849-940.

Deslauriers A, Rossi S, Anfodillo T, Saracino A (2008). Cambial phenology, wood formation and temperature thresholds in two contrasting years at high altitude in southern Italy. Tree Physiology 28: 863-871. - doi: 10.1093/treephys/ 28.6.863

Evert RF (2006). Esau's plant anatomy meristems, cells, and tissues of the plant body: their structure, function, and development. John Wiley and Sons, Hoboken, USA, pp. 624. [online] URL: http://books.google.com/books?id=oDhEB AoxgbkC

Fu J, Sun X, Wang J, Chu J, Yan C (2011). Progress in quantitative analysis of plant hormones. Chinese Science Bulletin 56: 355-366. - doi: 10.1007/ s11434-010-4243-8

Funada R, Kubo T, Tabuchi M, Sugiyama T, Fushitani $M$ (2001). Seasonal variations in endogenous indole-3-acetic acid and abscisic acid in the cambial region of Pinus densiflora stems in relation to earlywood-latewood transition and cessation of tracheid production. Holzforschung 55: 128-134. - doi: 10.1515/HF.2001.021

Gregory RA (1971). Cambial activity in Alaskan white spruce. American Journal of Botany 58: 160-171. - doi: 10.1002/j.1537-2197.1971.tbo9959.x Gričar J, Krze L, Cufar K (2009). Number of cells in xylem, phloem and dormant cambium in silver fir (Abies alba), in trees of different vitality. IAWA Journal 30: 121-133. - doi: 10.1163/229419 32-90000208

Gričar J, Prislan P, Gryc V, Vavrčík H, De Luis M, Cufar K (2014). Plastic and locally adapted phenology in cambial seasonality and production of xylem and phloem cells in Picea abies from temperate environments. Tree Physiology 34 (8): 869-881. - doi: 10.1093/treephys/tpu026

Gričar J, Prislan P, De Luis M, Gryc V, Hacurová J, Vavrčík H, Cufar K (2015). Plasticity in variation of xylem and phloem cell characteristics of norway spruce under different local conditions. Frontiers in Plant Science 6: 1-14. - doi: 10.3389/ fpls.2015.00730

Harris I, Jones PD, Osborn TJ, Lister DH (2013). Updated high-resolution grids of monthly cli- matic observations - the CRU TS3.10 dataset. International Journal of Climatology 34 (3): 623642. 10.1002/joc.3711

Jeffs RA, Northcote DH (1966). Experimental induction of vascular tissue in an undifferentiated plant callus. Biochemical Journal 101: 146152. - doi: 10.1042/bj1010146

Larson PR (1964). Some indirect effects of environment on wood formation. In: "The formation of wood in forest tress" (Zimmermann $\mathrm{MH}$ ed). Academic press, New York, USA, pp. 345365. - doi: 10.1016/B978-1-4832-2931-7.50024-0 Larson PR (1969). Wood formation and the concept of wood quality. Bulletin no. 74, Yale University, School of Forestry, New Haven, CT, USA, pp. 54. [online] URL: http://www.fs.usda. gov/treesearch/pubs/49814

Little CH, Savidge RA (1987). The role of plant growth regulators in forest tree cambial growth. Plant Growth Regulation 6 (1-2): 137169. - doi: 10.1007/BFo0043953

Lupi C, Morin H, Deslauriers A, Rossi S (2010). Xylem phenology and wood production: resolving the chicken-or-egg di lemma. Plant, Cell and Environment 33: 1721-1730. - doi: 10.1111/j.13653040.2010.02176.x

Nakurte I, Keisa A, Rostoks N (2012). Development and validation of a reversed-phase liquid chromatography method for the simultaneous determination of indole-3-acetic acid, indole-3pyruvic acid, and abscisic acid in barley (Hordeum vulgare L.). Journal of Analytical Methods in Chemistry 1: 1-6. - doi: 10.1155/2012/103575

Oribe Y, Funada R, Shibagaki M, Kubo T (2001). Cambial reactivation in locally heated stems of evergreen conifer Abies sachalinensis (Schmidt) masters. Planta 212: 684-691. - doi: $10.1007 /$ soo 4250000430

Perrot-Rechenmann C (2010). Cellular responses to auxin: division versus expansion. Cold Spring Harbor Perspectives in Biology 2: 1-15. - doi: 10.1101/cshperspect.a001446

Podlešáková K, Zalabák D, Cudejková M, Plíhal O, Szüčová L, Dolezal K, Spíchal L, Strnad M, Galuszka P (2012). Novel cytokinin derivatives do not show negative effects on root growth and proliferation in submicromolar range. PLoS ONE 7: 1-15. - doi: 10.1371/journal.pone.0039293 Rossi S, Deslauriers A, Morin H (2003). Application of the gompertz equation for the study of xylem cell development. Dendrochronologia 21: 33-39. - doi: 10.1078/1125-7865-00034

Rossi S, Anfodillo T, Menardi R (2006). Trephor: a new tool for sampling microcores from tree stems. IAWA Journal 27: 89-97. - doi: 10.1163/ 22941932-90000139

Savidge RA (1991). Seasonal cambial activity in Larix laricina saplings in relation to endogenous indol-3-ylacetic acid, sucrose, and coniferin. Forest Science 37: 953-958.

Schrader J, Baba K, May ST, Palme K, Bennett M, Bhalerao RP, Sandberg G (2003). Polar auxin transport in the wood-forming tissues of hybrid aspen is under simultaneous control of developmental and environmental signals. Proceedings of the National Academy of Sciences USA 100: 10096-10101. - doi: 10.1073/pnas.16336931 00

Sheen J, Zhou L, Jang JC (1999). Sugars as signaling molecules. Current Opinion in Plant Biology 2: 410-418. - doi: 10.1016/S1369-5266(99)0o014-X 
Sieburth LE, Deyholos MK (2006). Vascular development: the long and winding road. Current Opinion in Plant Biology 9: 48-54. - doi: 10.1016/ j.pbi.2005.11.008

Sundberg B, Little CHA, Riding RT, Sandberg G (1987). Levels of endogenous indole-3-acetic acid in the vascular cambium region of Abies balsamea trees during the activity-rest-quiescence transition. Physiologia Plantarum 71: 163170. - doi: 10.1111/j.1399-3054.1987.tbo2862.x

Sundberg B, Uggla C, Tuominen H (2000). Cambial growth and auxin gradients. In: "Cell and molecular biology of wood formation" (Savidge RA, Barnett JR, Napir R eds). Bios Scientific Publishers, Oxford, pp. 169-188.

Suzuki M, Yoda K, Suzuki H (1996). Phenological comparison of the onset of vessel formation between ring-porous and diffuse-porous deciduous trees in a japanese temperate forest. IAWA Journal 17: 431-444. - doi: 10.1163/22941 932-90000641

Taiz L, Zeiger E (2006). Plant Physiology (4 $4^{\text {th }}$ edn). Sinauer Associates Inc, Sunderland, UK, pp. 764 .
Teale WD, Paponov IA, Palme K (2006). Auxin in action: signalling, transport and the control of plant growth and development. Nature Reviews Molecular Cell Biology 7: 847-859. - doi: 10.1038/nrm2020

Tuominen H, Puech L, Fink S, Sundberg B (1997). A radial gradient of indole-3-acetic acid is related to secondary xylem development in hybrid aspen. Plant Physiology 115: 577-585. - doi: 10.1104/pp.115.2.577

Uggla C, Moritz T, Sandberg GG, Sundberg B (1996). Auxin as a positional signal in pattern formation in plants. Proceedings of the $\mathrm{Na}$ tional Academy of Sciences USA 93: 9282-9286. - doi: 10.1073/pnas.93.17.9282

Uggla C, Mellerowicz EJ, Sundberg B (1998). Indole-3-acetic acid controls cambial growth in Scots pine by positional signaling. Plant Physiology 117: 113-121. - doi: 10.1104/pp.117.1.113

Uggla C, Magel E, Moritz T, Sundberg B (2001). Function and dynamics of auxin and carbohydrates during early wood/latewood transition in Scots pine. Plant Physiology 125: 2029-2039. doi: 10.1104/pp.125.4.2029
Vanneste S, Friml J (2009). Auxin: a trigger for change in plant development. Cell 136: 10051016. - doi: 10.1016/j.cell.2009.03.001

Wodzicki TJ (1971). Mechanisms of xylem differentiation in Pinus sylvestris L. Journal of Experimental Botany 22: 670-687. - doi: 10.1093/jxb/ 22.3.670

Wetmore RH, Rier JP (1963). Experimental induction of vascular tissues in callus of angiosperms. American Journal of Botany 50: 418430. - doi: 10.1002/j.1537-2197.1963.tbo7210.x

\section{Supplementary Material}

Fig. S1 - Identification of cambial, phloem and xylem cells.

Fig. S2 - Measurement diagram of morphometric parameters of cells.

Link: Fajstavr_2734@supploo1.pdf 